\title{
Larvicidal effect of Clinopodium macrostemum essential oil extracted by microwave-assisted hydrodistillation against Culex quinquefasciatus (Diptera: Culicidae)
}

\author{
Alejandra Rojas-Olivos ${ }^{[1]}$, Rodolfo Solano-Gómez ${ }^{[1]}$, Carlos Granados-Echegoyen ${ }^{[2]}$, \\ Luis Alberto Santiago-Santiago ${ }^{[3]}$, Jorge García-Dávila ${ }^{[3]}$, \\ Rafael Pérez-Pacheco ${ }^{[1]}$ and Luicita Lagunez-Rivera ${ }^{[1]}$
}

\author{
[1]. Centro Interdisciplinario de Investigación para el Desarrollo Integral Regional, \\ Instituto Politécnico Nacional, Unidad Oaxaca, Santa Cruz Xoxocotlán; Oaxaca, México. \\ [2]. Cátedras CONACYT, Centro de Estudios en Desarrollo Sustentable y Aprovechamiento de la Vida Silvestre, \\ Universidad Autónoma de Campeche, San Francisco de Campeche, Campeche; México. \\ [3]. Departamento de Ingeniería en Biotecnología y Química,Universidad Politécnica de Tlaxcala, \\ San Pedro Xalcaltzinco Tepeyanco, Tlaxcala, México.
}

\begin{abstract}
Introduction: In the present study, we determined the chemical composition of Clinopodium macrostemum essential oil obtained by microwave-assisted hydrodistillation and its effect on the growth and development of Culex quinquefasciatus mosquito larvae. Methods: The essential oil compounds were identified by gas chromatography-mass spectrometry analysis, and bioassays were conducted to evaluate the influence on the developmental stages of early second instar larvae of $C x$. quinquefasciatus until the emergence of adults, using essential oil concentrations of 50,100, 200, 400, and $800 \mathrm{mg} / \mathrm{L}$. Results: The gas chromatographymass spectrometry analyses revealed that the leaf essential oil of $C$. macrostemum contained 32 compounds and the major chemical compounds identified were linalool (55.4\%), nerol (6.4\%), caryophyllene (6.25\%), menthone (5.8\%), geraniol acetate $(4.1 \%)$, terpineol $(3.7 \%)$, and pulegone $(2.8 \%)$. The essential oil yield obtained by microwave-assisted hydrodistillation was $0.8 \%$ at $20 \mathrm{~min}$. The treatments showed lethal concentrations (LC50 and LC90) of 22.49 and $833.35 \mathrm{mg} / \mathrm{L}$, respectively, after the final measurement of the total number of dead larvae (second, third, and fourth instars), and LC50 and LC90 of 6.62 and $693.35 \mathrm{mg} / \mathrm{L}$, respectively, at the end of the experimental period. The essential oil inhibited the growth and development of the mosquito larvae by $32 \%$ (relative growth index $=0.68$ ) at $50 \mathrm{mg} / \mathrm{L}$, and up to $47 \%$ (relative growth index $=0.53$ ) at $800 \mathrm{mg} / \mathrm{L}$. Conclusion: The present study demonstrated the larvicidal effect of C. macrostemum essential oil on Cx. quinquefasciatus, which can be attributed to the oxygenate compounds obtained by the extraction method.
\end{abstract}

Keywords: Caryophyllene. Filariasis. Gas chromatography-mass spectrophotometry. Linalool. Medicinal plants. Pennyroyal.

\section{INTRODUCTION}

Clinopodium macrostemum (Moc. \& Sessé ex Benth.) Kuntze is an aromatic herb or shrub in the family Lamiaceae, which reaches up to $2 \mathrm{~m}$ in height and is common in mountain areas with temperate or semi-cold climates from Central, Western, and Southern Mexico. In the past, this species has been known by the synonyms Melissa macrostema Moc. \& Sessé ex Benth., Calamintha macrostema (Moc. \& Sessé ex Benth.) Benth., and Satureja macrostema (Moc. \& Sessé ex Benth.) Briq ${ }^{1-3}$. Additionally, depending on the place where the species grows, it is known by various common names

Corresponding author: Dr. Luicita Lagunez-Rivera.

e-mail: 1lagunez@hotmail.com

Received 1 August 2017

Accepted 18 April 2018 including cuencuenzpatli or quauhnahuacense (Nahuatl from Central Mexico), guiezza or quieutzu (Zapotec from Oaxaca), hediondilla, hierba del borracho, menta, nurhitini o nurite (Purepechan from Michoacan), poleo, tabaquillo, té de monte, tragorigano, tuché, and yuujkxaky (Mixe from Oaxaca) ${ }^{4}$.

In Mexico, the traditional uses of $C$. macrostemum date back to pre-Hispanic times. Francisco Hernández, a Spanish physician who visited Nova Spain during the mid- $16^{\text {th }}$ century, reported several medicinal uses for this plant among the Mexican natives. Infusions of fresh leaves are used as a remedy for various gastrointestinal disorders, coughs, and to promote digestion ${ }^{2,5}$; tea infusions are used as drinking water or for relieving a hangover caused by the excessive consumption of alcoholic beverages; the leaves are used for seasoning foods or as milkweed; and the branches or leafy sticks, in the form of bunches, are utilized as adornments in religious and civil festivities ${ }^{4}$. 
Several Lamiaceae species have been evaluated for their larvicidal and insecticidal activities. For example, the aqueous extracts from Clinopodium laevigatum Stand. were evaluated against those from Culex quinquefasciatus (Say, 1983); however, they did not show any effectiveness ${ }^{6}$. The essential oil obtained by hydrodistillation from Clinopodium gracile (Benth.) Kuntze had a larvicidal effect on Aedes (Stegomyia) albopictus (Skuse, 1894), which is one of the two main vectors for dengue fever and malaria reported in $\mathrm{China}^{7}$, and the essential oil obtained by hydrodistillation from C. chinense (Benth.) Kuntze was reported as having insecticidal activity on Liposcelis bostrychophila (Badonnel, 1931 ${ }^{8}$. However, in the abovementioned studies, the essential oils were obtained with only hydrodistillation as the extraction method. Hydrodistillation at atmospheric pressure is routinely applied for the isolation of essential oils from plant material ${ }^{9}$ and, when assisted with microwaves, the combined method offers additional advantages, e.g., reduction in the isolation time, less environmental effects, less energy cost, and lower use of water as a solvent ${ }^{10,11}$. Conversely, the compounds present in the essential oils and their concentrations depend on the extraction method employed ${ }^{10}$; therefore, it is important to consider different extraction techniques to obtain the constituents and quantities required.

The family Culicidae is native to Mexico and has a great biodiversity containing 203 registered species, specifically 22 species from the subgenus Culex, highlighting $C x$. quinquefasciatus as being widely distributed in residential and agricultural areas ${ }^{12}$. This mosquito species is an important vector for the dissemination of arboviruses such as Zika, which has an important influence because it can increase the cases of Guillen-Barré and congenital syndrome ${ }^{13}$, and lymphatic filariasis ${ }^{14}$, with the World Health Organization reporting that 856 million people in 52 countries are threatened by this disease and are in need of prophylactic treatment. The traditional control for this mosquito species is via dichlorodiphenyltrichloroethane (DDT) and pyrethroid insecticides ${ }^{15}$; however, it has become resistant to a wide range of chemical pesticides ${ }^{16,17}$. Another alternative to control this species is by biopesticides such as Bacillus sphaericus (Neide, 1904); however, a study by Fajar et al. ${ }^{18}$ reported only a mild toxicity in this mosquito species and others from genus Culex. The use of essential oils obtained from plants ${ }^{19}$ has been reported as an alternative control for $C x$. quinqufasciatus and could be environmentally friendly as they are a botanical derivative, for which the composition and quality employed are very important and depend on the nature of the plant material and the extraction method applied ${ }^{20}$. The aim of the present study was to perform a qualitative analysis and characterization of the chemical composition of the essential oil obtained by microwave-assisted hydrodistillation (MAH) from C. macrostemum, and evaluate the larvicidal effect of this essential oil on $C x$. quinquefasciatus as an important arbovirus vector.

\section{METHODS}

\section{Plant material}

Fresh leaves were collected from plants without flowers that were growing in forest in the Santa Maria Huitepec village, municipality of Totontepec Villa de Morelos, in the Mixe region of Oaxaca state, Mexico, with previous permission from the local authority. A voucher specimen was pressed and deposited in the herbarium of the Centro Interdisciplinario de Investigación para el Desarrollo Integral Regional (OAX) Unidad Oaxaca.

\section{Extraction kinetics}

The plant material was dried at average environmental temperature of $28^{\circ} \mathrm{C}$ and rehydrated $45 \mathrm{~min}$ before MAH. The extraction method was performed in an aromatic water recirculation system adapted with a MW1235WB microwave (SAMSUNG, Seoul, South Korea) using a 1:10 (w/v) relationship from $100 \mathrm{~g}$ of plant material and $1,000 \mathrm{~mL}$ of water, with a irradiation frequency of $2450 \mathrm{MHz}$. The essential oil extracted was quantified every $10 \mathrm{~min}$ (radiation time) and left to stand for $5 \mathrm{~min}$; the extraction was stopped when three successive quantifications remained constant. Every extraction kinetic was performed in triplicate.

\section{Gas chromatography-mass spectrophotometry identification}

Gas chromatography-mass spectrophotometry (GC-MS) analysis was performed using an Agilent $6890 \mathrm{~N}$ coupled to a JEOL-JMS-GC-MATE III. Samples were analyzed on a fused silica capillary column HP5MS $(30 \mathrm{~m} \times 0.32 \mathrm{~mm}$ I.D., film thickness $0.25 \mu \mathrm{m}$ ), with helium as the carrier gas, injector and detector temperatures set at $300^{\circ} \mathrm{C}$, injected volume of $1 \mu \mathrm{L}$, oven temperature programmed at $30^{\circ} \mathrm{C}$ with increases of $8^{\circ} \mathrm{C} /$ min up to $300^{\circ} \mathrm{C}$, and ionization energy of $70 \mathrm{eV}$. Identification of the component was based on computer matched NIST 98 and the Dictionary of Natural Products ${ }^{21}$.

\section{Collection of egg rafts and maintenance of mosquito larvae}

The egg rafts of $C x$. quinquefasciatus were collected from standing water in the facilities of the Research Interdisciplinary Centre for Regional Integral Development (CIIDIR- Oaxaca). The egg rafts were taken to the CIIDIR-Oaxaca bioplant laboratory and individually placed into plastic trays of $47 \mathrm{~cm}$ $\times 35 \mathrm{~cm} \times 12 \mathrm{~cm}$ containing $300 \mathrm{~mL}$ of water for biological development. Mosquito larvae were fed with a sprayed product used to feed fish (Api-barge).

\section{Preparation of the essential oil concentrations for application}

From the essential oil stock solution, $0.008 \mathrm{~mL}$ was solubilized using Tween-20 ( $0.01 \%$ of polysorbate) as the emulsifier agent and diluted in $10 \mathrm{~mL}$ of distilled water to prepare a serial dilution of test concentrations. Serial dilutions at concentrations of 50, $100,200,400$, and $800 \mathrm{mg} / \mathrm{L}$ were performed for each of the 80 larvae tested, assigned in quadruplicate.

\section{Evaluation of larvicidal activity based on the essential oil composition}

Mosquito larvicidal assays were performed based on the methodology of the World Health Organization Standard Procedures with slight modifications ${ }^{6}$. Twenty-eight days 
after the treatment application, early second instar larvae of Cx. quinquefasciatus were observed to measure the influence of the different essential oil concentrations on the developmental stages (second, third, and fourth instars, pupae and adults). For each treatment, groups of 20 larvae were selected and placed into a plastic beaker with $99 \mathrm{~mL}$ of distilled water and $1 \mathrm{~mL}$ of the essential oil concentration to be evaluated. The mortality induced by the essential oil was evaluated using two criteria: I) when inside the plastic beaker, larvae did not show movement that was similar to that exhibited by larvae from the control group, then the larvae was considered to be dead; and II) when larvae was disturbed with a brush to the siphon in its cervical region and it did not show any reaction, it was considered dead. Each treatment was replicated four times. Dead and live larvae and pupae were counted and removed daily from each developmental stage, as well as the number of emergent adults measured $^{22}$. Measurements of larval and pupal mortality, and adult emergence were recorded to calculate the relative growth index (RGI) using the following formula:

$R G I=\frac{\left.\sum_{1}^{4} \text { (Number of insect alive } * \text { insect phase }\right)+\sum_{1}^{4}[\text { Number of dead insect } *(\text { insect phase }-1)]}{\text { N }}$ (Total number of insects evaluated $*$ total number of insect phases)

The control group (no treatment application), containing 80 larvae, were conditioned with $400 \mathrm{~mL}$ of distilled water.

\section{Statistical analysis}

Bioassays were established under a completely randomized design. The Minitab v17.0 system analysis of variance procedure was used and significant differences to $p<0.01$ were calculated. The average larval mortality (LM) (second, third, and fourth instars) up to the calculation of RGI and total mortality (TM) (second, third, and fourth instars, pupae and adult) at the end of the experimental period were subjected to probit analysis to calculate the lethal concentration a half (LC50) and 90\% (LC90) of mosquito population and chi-square values. In all tests, no mortality was detected unless essential oil had been provided as a stimulus; therefore, no correction was required based on the Abbott formula.

\section{RESULTS}

\section{Chemical composition of Clinopodium macrostemum essential oil}

The yield of essential oil extracted from the dried leaves of C. macrostemum by MAH was $0.8 \%(1: 10 \mathrm{w} / \mathrm{v})$ with an isolation time of $20 \mathrm{~min}$. Table 1 shows a total of 32 compounds that were identified in the essential oil. The major compounds were linalool (55.4\%), nerol (6.4\%), caryophyllene (6.3\%), menthone $(5.8 \%)$, geraniol acetate $(4.1 \%)$, terpineol $(3.7 \%)$, and pulegone $(2.8 \%)$.

\section{Larvicidal activity}

The essential oil extracted from C. macrostemum had affectivity against larvae of the mosquito $C x$. quinquefasciatus. Table 2 shows that the effect of the essential oil was high when early second instar larvae developed into the fourth instar stage, which indicates that the essential oil exerted pressure on insect development. The essential oil at a concentration of $50 \mathrm{mg} / \mathrm{L}$ ensured a LM of $63.8 \%$ (in the fourth larval stage); however, when the dead pupae percentage was added at the end of the experimental period, the TM was increased to $72.5 \%$. The mortality provoked by a $400 \mathrm{mg} / \mathrm{L}$ essential oil concentration increased from $86.3 \%$ (LM) to $90.0 \%$ (TM). The highest concentration of essential oil $(800 \mathrm{mg} / \mathrm{L})$ did not record any variation between LM and TM owing to the fact that the remaining $10 \%$ formed into pupae (i.e., were alive). The essential oil had a significant toxic effect on mosquito larvae of Cx. quinquefasciatus. Table 3 shows the lethal concentrations of LC50 and LC90 as being 22.49 and $833.35 \mathrm{mg} / \mathrm{L}$, respectively, when measuring the total number of dead larvae (second, third, and fourth instars), and LC50 and LC90 of 6.62 and $693.35 \mathrm{mg} / \mathrm{L}$, respectively, at the end of the experimental period, when the number of dead pupae were added to the total number of dead larvae. Additionally, the essential oil inhibited the growth and development of the mosquito larvae at a rate of $32 \%(\mathrm{RGI}=0.68)$ in the lowest concentration $(50 \mathrm{mg} / \mathrm{L})$ and up to $47 \%(\mathrm{RGI}=0.53)$ in the highest concentration $(800 \mathrm{mg} / \mathrm{L})$, compared to the control group that had a RGI of 1.04. The emulsifier agent (Tween- $20=0.01 \%$ of polysorbate) was tested and did not show any biological activity against the mosquito developmental stages, which was the same as the data obtained for the control group (no treatment application). This showed that the inert suspension did not interfere with the development of the mosquito larvae.

\section{DISCUSSION}

The importance of public health care should be considered from the control of arbovirus vectors from their larval stage to stop global expansion of diseases. It is important to develop environmentally friendly biocontrol mechanisms that are not resistant to adaptations of mosquito species such as those developed by synthetic pesticides in species of the genus Culex. The present study is the first to report on the bioactivity of essential oil from C. macrostemum for the control of $C x$. quinquefasciatus mosquito larvae. An early evaluation using aqueous extract from similar species did not show any activity against this mosquito ${ }^{6}$. The extraction method used in the present study was useful for evaluating the insecticidal properties of C. macrostemum. This is because the microwave-assisted extraction method is a more efficient method for this purpose because it enables the enhancement of several of the extracted essential oil properties, including toxicity, antimicrobial and larvicidal activities, in comparison to that obtained by conventional techniques ${ }^{10,22-24}$. The major compounds identified in the present study and larvicidal activity against the mosquito species have been found in other Lamiaceae species and therefore represent a defense and attack system for Cx. quinquefasciatus. Our results showed a mortality effectiveness of up to $80 \%$ with an essential oil concentration of $400 \mathrm{mg} / \mathrm{L}$, with similar results reported by Ansari et al. ${ }^{25}$ for the larvicidal activity of Mentha piperita L. essential oil against $C x$. quinquefasciatus, in which were present several of the major compounds identified in the present study. In this respect, several monoterpenes such 
Rojas-Olivos A et al. - Larvicidal effect of Clinopodium macrostemum

TABLE 1: Chemical composition of the essential oil obtained from Clinopodium macrostemum dried leaves by microwave- assisted hydrodistillation.

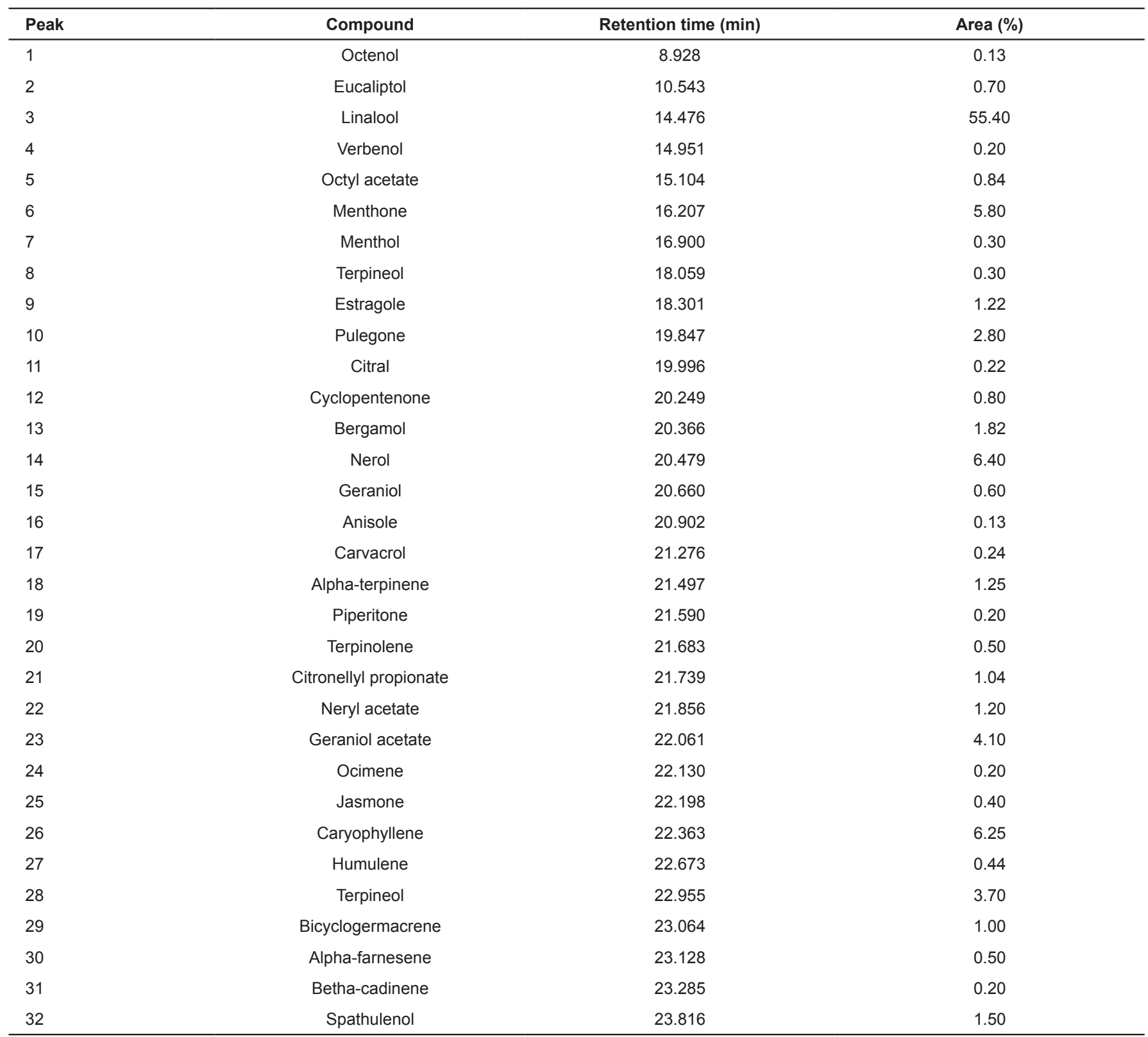

TABLE 2: Mortality (\%) from the developmental stages of the second instar larvae of Culex quinquefasciatus treated with Clinopodium macrostemum essential oil obtained by microwave-assisted hydrodistillation.

\begin{tabular}{|c|c|c|c|c|c|c|c|c|c|c|c|c|c|c|}
\hline \multirow[b]{2}{*}{$\mathrm{C}(\mathrm{mg} / \mathrm{L})$} & \multicolumn{12}{|c|}{ Developmental stages } & & \\
\hline & mean & SD & mean & SD & mean & SD & mean & SD & mean & SD & mean & SD & mean & SD \\
\hline 800 & $5.00 a$ & 2.30 & $6.25 a$ & 2.86 & $78.75 a$ & 13.15 & $90.00 a$ & 4.08 & $0 a$ & 0 & $90.00 a$ & 4.08 & $0.53 d$ & 0.05 \\
\hline 400 & $3.75 a$ & 1.90 & $5.00 \mathrm{a}$ & 2.70 & $77.50 a$ & 6.45 & $86.25 a$ & 7.50 & $3.75 a$ & 7.50 & $90.00 \mathrm{a}$ & 0 & $0.55 \mathrm{~cd}$ & 0.02 \\
\hline 200 & $0 b$ & 0 & $3.75 a$ & 1.82 & $72.50 \mathrm{a}$ & 15.45 & $76.25 a b$ & 19.31 & $3.75 a$ & 7.50 & $80.00 \mathrm{ab}$ & 12.91 & $0.62 \mathrm{bcd}$ & 0.09 \\
\hline 50 & $0 b$ & 0 & 0c & 0 & $63.75 a$ & 6.30 & $63.75 b$ & 6.29 & $8.75 a$ & 4.79 & $72.50 \mathrm{~b}$ & 10.40 & $0.68 \mathrm{~b}$ & 0.04 \\
\hline Control & $0 b$ & 0 & $0 c$ & 0 & $\mathrm{Ob}$ & 0 & $0 c$ & 0 & $0 a$ & 0 & $0 c$ & 0 & $1.04 a$ & 0 \\
\hline
\end{tabular}

Data represent means of the experiments performed in triplicates $(n=3)$. Means followed by different letters within the same developmental stage are significantly different at $\mathrm{P}<0.01$ compared to the control group. II: second instar larvae; III: third instar; IV: fourth instar; C: concentration; LM: larval mortality; DP: dead pupae; TM: total mortality at the end of the experiment. RGI: relative growth index; SD: standard deviation. 
TABLE 3: Lethal concentrations and regression analysis of developmental stage of early second instar mosquito larvae of Culex quinquefasciatus treated with the essential oil of Clinopodium macrostemum.

\begin{tabular}{ccccccc}
\hline Stage Exposure & LC50* & LC90* & SE & X $^{2}(\boldsymbol{d f})$ & $\boldsymbol{z}$-value & $\boldsymbol{p}$-value \\
\hline LM & $22.49(5.06-44.01)$ & $833.35(465.89-2904.54)$ & 0.074 & $0.82(3)$ & 4.74 & 0.84 \\
TM & $6.62(0.12-22.49)$ & $693.35(353.86-4732.69)$ & 0.077 & $1.15(3)$ & 3.55 & 0.76 \\
\hline
\end{tabular}

LC: lethal concentration; LC50: lethal concentration that control a half of mosquito population; LC90: lethal concentration that control $90 \%$ of mosquito population SE: standard error; $\mathbf{X}^{2}(\boldsymbol{d} f)$ : chi-squared value (degrees of freedom); $\mathbf{z}$-value: test statistic value (z-score); $\boldsymbol{p}$-value: probability value; LM: larval mortality; TM: total mortality. *Values in parentheses indicate the lower and upper $95 \%$ confidence limits.

as carvacrol, p-cymene, linalool, $\alpha$-terpinene, and thymol from C. hortense (L.) Kuntze and Thymus sp. have shown activity against $C x$. pipiens ${ }^{26,27}$. Nerol from Mentha species has been tested for its insecticidal properties ${ }^{23}$. Govindarajan et al..$^{28}$ reported that the essential oil from Ocimum basilicum L. had significant activity against late third stage larvae of $C x$. tritaeniorhynchus (Giles, 1901), Aedes albopictus, and Anopheles subpictus (Grassi, 1899), with linalool being the major chemical compound identified in this essential oil. Likewise, essential oil from Hyptis suaveolens L. (Poit. 1806) showed insecticidal activity against Ae. albopictus larvae, where the mortality was dosage dependent, i.e., highest dosages had highest mortality, whereas lowest dosages had lowest mortality ${ }^{29}$.

Considering the presence of caryophyllene $(6.3 \%)$ in the essential oil identified from C. macrostemum, it is possible to compare it with other species of genus Clinopodium, as reported by Chen et al. ${ }^{7}$, who documented a strong larvicidal activity of essential oil from C. gracile aerial parts against the fourth instar larvae of Ae. albopictus. This previous study reported a higher content of sesquiterpenoids $(70.5 \%)$ than monoterpenoids $(12.2 \%)$ and one of the major compounds was caryophyllene (5.2\%), which was similar to the present study.

Another important compound identified in the present study was linalool, which exhibited the highest percentage (55.4\%) and has been identified in the essential oils of Lavandula gibsoni Graham and Plectranthus mollis (Aiton) Spreng. Both plants have activity against fourth instar larvae of mosquitos such as Aedes (Stegomyia) aegypti (Linnaeus, 1762), Anopheles stephensi Liston, and $C x$. quinquefasciatus ${ }^{30}$. Among the major components identified in these essential oils were linalool for L. gibsoni (the more abundant compound in the present study) and piperitone for P. mollis. It was reported by Borges de Castro et al. ${ }^{31}$ that the synergic effect of all compounds in essential oils could enhance their larvicidal effectiveness, which is shown by the direct relationship between concentration and mortality effect.

We demonstrated for the first time the effect of the essential oil of $C$. macrostemum on $C x$. quinquefasciatus mosquito larvae. The extraction method employed in the present study (MAH) could be responsible for the larvicidal effectiveness of the essential oil obtained. The results show the potential of this essential oil as a means of biological control for mosquitoes, which are vectors of diseases with high incidence in the tropics and constitute a serious public health problem. The essential oil evaluated here shows a high effectiveness against Cx. quinquefasciatus, since it provoked a TM of this mosquito species as high as $72.5 \%$ in a concentration as low as $50 \mathrm{mg} / \mathrm{L}$. The results could be useful in the search for newer, safer, and more effective natural larvicidals and inhibitors of growth agents against $C x$. quinquefasciatus.

\section{Acknowledgments}

We acknowledge the local authorities of Santa María Huitepec, Oaxaca, Mexico for the use of their facilities that were provided for the plant material collection.

\section{Conflict of interest}

The authors declare that there is no conflict of interest.

\section{Financial support}

The authors sincerely thank the Consejo Nacional de Ciencia y Tencología (CONACYT) for financial support through the CONACYT project 270428. The authors would also like to thank the Comisión de Operación y Fomento de Actividades Académicas of the Instituto Politécnico Nacional and to the Programa Nacional de Movilidad Estudiantil (ECOES) Santander for the awarded scholarships.

\section{REFERENCES}

1. Harley RM, Paucar AG. List of species of tropical American Clinopodium (Labiatae), with new combinations. Kew Bull. 2000;55(4):917-27.

2. Martínez M. Las plantas medicinales de México, $7^{\text {th }}$ edición, México: Ediciones Botas; 2005. 625p.

3. Martínez-Gordillo M, Fragoso-Martínez I, García-Peña MR, Montiel O. Géneros de Lamiaceae de México, diversidad y endemismo. Rev Mex Biodiv. 2013;84(1):30-86.

4. Ortega-Ortega T, Vázquez-García V. Satureja macrostema: situación ambiental, conocimiento local y roles de género. Madera y Bosques. 2014;20(2):71-86.

5. Hernández F. Historia Natural de Nueva España. Obras Completas; Tomos II y III. México: Universidad Nacional Autónoma de Mexico, 1959. 150 p.

6. Pérez-Pacheco R, Rodríguez C, Lara J, Montes R, Ramírez G. Toxicidad de aceites, esencias y extractos vegetales en larvas de mosquitos Culex quinquefasciatus Say (Díptera: Culicidae). Acta Zool Mex. 2004;20(1):141-52.

7. Chen XB, Liu XC, Zhou L, Liu ZL. Essential Oil Composition and Larvicidal Activity of Clinopodium gracile (Benth) Matsum (Labiatae) Aerial Parts against the Aedes albopictus Mosquito. Trop J Pharm Res. 2013;12(5):799-804. 
8. Li HY, Liu XC, Chen XB, Liu QZ, Liu ZL. Chemical composition and insecticidal activities of the essential oil of Clinopodium chinense (Benth.) Kuntze Aerial Parts against Liposcelis bostrychophila Badonnel. J Food Prot. 2015;78(10):1870-4.

9. Bakkali F, Averbeck S, Averbeck D, Idaomar M. Biological effects of essential oils-a review. Food Chem Toxicol. 2008;46(2):446-75.

10. Zhang H-F, Yang X-H, Eang Y. Microwave assisted extraction of secondary metabolites from plants: Current status and future directions. Trend in Food Sci \& Technol. 2011;22(12):672-88.

11. Kosar M, Özek T, Kürkcüoglu M, Hüsnü Can Baser K. Comparison of microwave-assisted hydrodistillation and hydrodistillation methods for the fruit essential oils of Foeniculum vulgare. J Essent Oil Res. 2007;19(5):426-9.

12. La Pointe DA, Goff ML, Atkinson CT. Comparative susceptibility of introduced forest-dwelling mosquitoes in Hawai' $i$ to avian malaria, Plasmodium relictum. J Parasitol. 2005; 91(4):843-9.

13. Del Carpio-Orantes L, González-Clemente MC, Lamothe-Aguilar T. Zika and its vector mosquitoes in Mexico. J Asia Pac Biod 2018; https://doi.org/10.1016/j.japb.2018.01.002.

14. Soonwera M, Phasomkusolsil S. Adulticial, larvicidal, pupicidal and oviposition deterrent activities of essential oil from Zanthoxylum limonella Alston (Rutaceae) against Aedes aegypti (L.) and Culex quinquefasciatus (Say). Asian Pac J Trop Med. 2017;7(11):967-78.

15. Kudom AA, Mensah BA, Froeschi G, Rinder H, Boakye D. DDT and pyrethroid resistance status and laboratory evaluation of bio-efficacy of long lasting insecticide treated nets against Culex quinquefasciatus and Culex decens in Ghana. Acta Trop. 2015;150:122-30.

16. Corbel V, N'Guessan R, Brengues C, Chandre F, Djogbenou L, Martin T, et al. Multiple insecticide resistance mechanisms in Anopheles gambiae and Culex quinquefasciatus from Benin, West Africa. Acta Trop. 2007;101(3):207-16.

17. Chandre F, Darriet E, Darder M, Cuany A, Doannio JMC, Pasteur $\mathrm{N}$, et al. Pyrethroid resistance in Culex quinquefasciatus from West Africa. Med and Vet Entomol. 1998;12(4):359-66.

18. Suryadi BF, Yanuwiadi B, Ardyati T, Suharjono S. Evaluation of enthomopathogenic Bacillus sphaericus isolated from Lombok beach area against mosquito larvae. Asian Pac J Trop Biomed. 2016;6(2):148-54.

19. Mulla MS, Su T. Activity and biological effects of neem products against arthropods of medical and veterinary importance. J Am Mosq Contr Assoc. 1999;15(2):133-52.
20. Lagunez-Rivera L, Vilarem G. Hydrodistillation of caraway by direct induction heating assisted by a magnetic field process. Flavour Frag J. 2007;22:178-83.

21. Buckingham J. Dictionary of Natural Products. Boca Raton: Chapman and Hall/CR Press, Taylor \& Francis Group; 2017.

22. Granados-Echegoyen C, Pérez-Pacheco R, Alonso-Hernández N, Vásquez-López A, Lagunez-Rivera L, Rojas-Olivos A. Chemical characterization and mosquito larvicidal activity of essential oil from leaves of Persea Americana Mill (Lauraceae) against Culex quinquefasciatus (Say). Asian Pac J Trop Dis. 2015;5(6):463-7.

23. Kumar P, Mishra S, Malik A, Satya S. Insecticidal properties of Mentha species: A review. Ind Crops Prod. 2011;34(2011):802-17.

24. Thach L N, Nhung TH, Vo TN, Tran H-A. The new rich of rotundifolone: Mentha aquatica Linn. var. crispa oil from microwaveassisted hydrodistillation. J Essent Oil Res. 2013;25(1):39-43.

25. Ansari MA, Vasudevan P, Tandon M, Razdan RK. Larvicidal and mosquito repellent action of peppermint (Mentha piperita) oil. Biores Technol. 2000;71(3):267-71.

26. Park BS, Choi WS, Kim KH, Lee SE. Monoterpenes from thyme (Thymus vulgaris) as potential mosquito repellents. J Am Mosq Control Assoc. 2005;21(1):80-3.

27. Pavela R. Larvicidal property of essential oils against Culex quinquefasciatus Say (Diptera: Culicidae). Ind Crops Prod. 2009;30(2):311-5.

28. Govindarajan M, Sivakumar R, Rajeswary M, Yogalakshmi K. Chemical composition and larvicidal activity of essential oil from Ocimum basilicum (L.) against Culex tritaeniorhynchus, Aedes albopictus and Anopheles subpictus (Diptera: Culicidae). Exp Parasitol. 2013;134(1):7-11.

29. Conti B, Benelli G, Flamini G, Cioni PL, Profeti R, Ceccarini L, et al. Larvicidal and repellent activity of Hyptis suaveolens (Lamiaceae) essential oil against the mosquito Aedes albopictus Skuse (Diptera: Culicidae). Parasitol Res. 2012;110(5):2013-21.

30. Kulkarni RR, Pawar PV Joseph MP, Akulwad AK, Sen A, Joshi SP. Lavandula gibsoni and Plectranthus mollis essential oils: chemical analysis and insect control activities against Aedes aegypti, Anopheles stephensi and Culex quinquefasciatus. J Pest Sci. 2013;86:713-8.

31. de Castro DS, da Silva DB, Tibúrcio JD, Sobral MEG, Ferraz V, Taranto AG, et al. Larvicidal activity of essential oil of Peumus boldus Molina and its ascaridole-enriched fraction against Culex quinquefasciatus. Exp Parasitol. 2016;171:84-90. 